\title{
MicroRNA-27b Expression in Rats Submitted to Physical Exercise and Experimental Cerebral Ischemia
}

\author{
Expresión de MicroRNA-27b en Ratas Sometidas a \\ Ejercicio Físico e Isquemia Cerebral Experimental
}

\begin{abstract}
Brenno Marco De Russi ${ }^{1}$; Lucas Barbosa Porsani ${ }^{2}$; Mucio Luiz de Assis Cirino ${ }^{2,3}$; Jairo Pinheiro da Silva ${ }^{2}$; Letícia Passi Turra ${ }^{2}$; Paulo Cezar Novais ${ }^{2,4}$; Fermino Sanches Lizarte Neto ${ }^{2}$ : Valéria de Paula Sassoli Fazan²; José Antônio Thomazini ${ }^{2}$; Benedicto Oscar Colli ${ }^{2}$; Daniela Pretti da Cunha Tirapelli ${ }^{2}$; Luis Fernando Tirapelli ${ }^{2} \&$ Camila Albuquerque Melo de Carvalho $^{1}$
\end{abstract}

DE RUSSI, B. M.; PORSANI, L. B.; CIRINO, M. L. A.; SILVA, J. P.; TURRA, L. P.; NOVAIS, P. C.; LIZARTE NETO, F. S.; FAZAN, V. P. S.; THOMAZINI, J. A.; COLLI, B. O.; TIRAPELLI, D. P. C.; TIRAPELLI, L. F. \& CARVALHO, C. A. M. MicroRNA$27 \mathrm{~b}$ expression in rats submitted to physical exercise and experimental cerebral ischemia. Int. J. Morphol., 39(3):754-758, 2021.

SUMMARY: Cerebral ischemia has not only a high mortality rate, which is the second leading cause of death worldwide, but is also responsible for severe disabilities in working age individuals, generating enormous public expending for treatment and rehabilitation of the affected individuals. The role of microRNAs in the pathophysiology of cerebral ischemia has been highlighted in current investigations. In addition, recent studies have also highlighted physical exercise as a possible protective factor both in the prevention and in the effects of cerebral ischemia, placing it as an important study resource. Thus, we investigated the role of physical exercise in experimental cerebral ischemia associated with the expression of microRNA-27b. 16 animals were used, divided into four experimental groups: Control, Physical Exercise, Cerebral Ischemia and Cerebral Ischemia associated with Physical Exercise. The real-time PCR methodology was used to analyze the expression of microRNA-27b. Although there were no statistically significant differences in the expression of microRNA-27b between the groups studied, the increased expression of microRNA-27b in the Physical Exercise group indicates its neuroprotective role in the pathophysiology of cerebral ischemia.

KEY WORDS: Cerebral ischemia; Physical exercise; MicroRNAs; MicroRNA-27b.

\section{INTRODUCTION}

According to the World Health Organization (WHO) in 2016, strokes were the second leading cause of death and the third leading cause of disability in the world. In less developed countries the incidence of stroke has more than doubled in the last forty years, while in more developed countries, in the same period, there was a decrease of about $42 \%$ (Feigin et al., 2014).

Brain ischemia is characterized, according to Wanchao et al. (2018), by the interruption of cerebral blood flow and consequent tissue deprivation of oxygen and glucose, necessary for cellular metabolism. According to Shamsaei et al. (2015), after a stroke, cerebral edema occurs and is one of the most important causes of neuronal death, as well as the development of brain injuries. Thus, it is mandatory to take action not only to prevent the development of brain lesions and edema but also to restrain subsequent neurological damage.
It is expected that the incidence of stroke increases in the forthcoming decades, partly due to the population aging and the increasing incidence of comorbidities such as diabetes, obesity, and smoking. Immobility is a risk factor for stroke. The protective effects of exercise apply to all age groups, races, and both sexes. The usefulness of exercise is due to the positive effects on blood pressure, body weight, blood lipids, and sugar control (Sveinsson et al., 2014).

Rodents are the main animals used in physical exercise protocols related to the study of brain functions and their mechanisms in experimental research (Aguiar Jr. \& Pinho, 2007). In situations where physical exercise precedes cerebral ischemia, it promotes cerebral neuroprotection in rats, among the mechanisms involved, we can highlight the decrease in the inflammatory reaction, the decrease in cerebral edema, and the increase in neuronal tissue protective

\footnotetext{
${ }^{1}$ Centro Universitário Barão de Mauá, Ribeirão Preto, SP, Brasil.

${ }^{2}$ Universidade de São Paulo, Faculdade de Medicina de Ribeirão Preto, Departamento de Cirurgia e Anatomia Ribeirão Preto, SP, Brasil.

${ }^{3}$ Universidade de Marília (UNIMAR), Marília, SP, Brasil, Programa Mestrado em Interações Estruturais e Funcionais em Reabilitação.

${ }^{4}$ Universidade Anhanguera, Ribeirão Preto, SP, Brasil.
} 
DE RUSSI, B. M.; PORSANI, L. B.; CIRINO, M. L. A.; SILVA, J. P.; TURRA, L. P.; NOVAIS, P. C.; LIZARTE NETO, F. S.; FAZAN, V. P. S.; THOMAZINI, J. A.; COLLI, B. O.; TIRAPELLI, D. P. C.; TIRAPELLI, L. F. \& CARVALHO, C. A. M. MicroRNA-27b expression in rats submitted to physical exercise and experimental cerebral ischemia. Int. J. Morphol., 39(3):754-758, 2021.

proteins (Damázio et al., 2015). The greatest benefit of pre-ischemic physical exercise is the optimization of the ability to maintain energy supply, in addition to several other mechanisms that allow containment of the damage caused in the nervous tissue by ischemia (Dornbos 3rd et al., 2013).

Recent studies investigate the role of physical exercise associated with cerebrovascular diseases. Currently, some therapeutic approaches that use physical exercise are being studied with a focus on rehabilitation in experimental cerebral ischemia models.Regular physical exercise has a great role in improving the quality of life and has been used as a mechanism of neuroprotection. The integration of several brain neuronal impulses allows plastic changes that benefit the brain structures compromised due to the injury (Garbuzova-Davis et al., 2013). Physical exercise is essential in our daily routine to maintain the general well-being of the body and especially the nervous system. In the last decades, many studies have shown that physical exercise improves cognitive skills and lack of exercise can lead to the incidence of several neurological disorders (Fernandes et al., 2017).

Interest in aspects related to the organism's response to exercise in a genetic context has been growing, in which microRNAs sPem to play a fundamental role (Downing $\&$ Balady, 2011). MicroRNAs are non-coding endogenous single-stranded RNA molecules and function as negative regulators of the expression of more than half of the protein coding genes by inhibiting or degrading the target mRNA translation. They can simultaneously regulate targets that participate in the physiological processes of cerebral ischemia and are considered not only promising therapeutic agents in stroke, but also as potential biomarkers of the pathophysiological processes of cerebral ischemia (Liu et al., 2019). Recently, some studies have highlighted microRNAs as potential brain biomarkers that are involved in molecular mechanisms such as apoptosis, synaptic plasticity, proliferation, memory acquisition and loss, and differentiation (Cirino et al., 2019). Experiments with mice submitted to physical exercise after traumatic brain injury, performed by Bao et al. (2014), obtained as results 32 microRNAs differentially expressed, of which 12 were hypoexpressed, and 20 were overexpressed.

This study aimed to evaluate the expression of microRNA-27b in rats submitted to the experimental model of cerebral ischemia due to occlusion of the middle cerebral artery (MCAO) for 60 minutes followed by reperfusion of 24 hours associated with the performance of pre-ischemic exercise.

\section{MATERIAL AND METHOD}

This study was approved by the Animal Experimentation Committee (CETEA) of the Ribeirão Preto School of Medicine - University of São Paulo (FMRP-USP) and all procedures were carried out following the Ethical Principles for Experimental Animals (COBAO), the protocol associated permit number 213/2017. The 16 adult male rats (Rattus norvegicus) weighing 280-310g were randomly divided into four experimental groups:

- Control Group (C): four animals that, after anesthesia and stabilization of biological variables, were euthanized without undergoing the surgical procedure.

- Physical Exercise Group (PE): four animals that, after physical training for four weeks, were euthanized without undergoing the surgical procedure.

- Cerebral Ischemia Group (I): four animals subjected to focal ischemia due to occlusion of the middle cerebral artery for 60 minutes, followed by $24 \mathrm{hr}$ reperfusion.

- Physical Exercise + Cerebral Ischemia Group $(\mathrm{PE}+\mathrm{I})$ : four animals that after physical training for four weeks, underwent focal ischemia due to occlusion of the middle cerebral artery for 60 minutes, followed by $24 \mathrm{hr}$ reperfusion.

General procedures. The general procedures were performed at the Experimental Neurosurgery Laboratory (Surgical Technique and Experimental Surgery Laboratory, Department of Surgery and Anatomy at FMRP-USP), as described (Carlotti Junior et al., 2001).

Cerebral ischemia induction. Animals were partially anesthetized with halothane inhalation and intubation with an orotracheal tube. Occlusion of the middle cerebral artery was performed through the external carotid artery (ECA), which was cranially ligated and sectioned for retrograde insertion of a $2.5 \mathrm{~cm}$ mononylon 4-0 obstructive thread with a thickened silicone tip over an extension $5 \mathrm{~mm}$. The wire was introduced until it reached the common carotid artery (CCA) and progressed cranially through the internal carotid artery (ICA) to the point where it obstructs the middle cerebral artery (Carlotti Junior et al.).

Physical exercise protocol. After a five-day treadmill adaptation period (to reduce the animal stress) with progressive speeds ( 5 to $18 \mathrm{~m} / \mathrm{min}$ ) and durations (5 to 15 min), the 4-week protocol was started: first, a period of warm up that consisted of $2 \mathrm{~min}$ at a speed of $5 \mathrm{~m} / \mathrm{min}$ and then, gradually the speed was increased until reaching the speed of $18 \mathrm{~m} / \mathrm{min}$ in which the animals remained for 30 minutes always with 0 degrees of inclination. Animals that 
DE RUSSI, B. M.; PORSANI, L. B.; CIRINO, M. L. A.; SILVA, J. P.; TURRA, L. P.; NOVAIS, P. C.; LIZARTE NETO, F. S.; FAZAN, V. P. S.; THOMAZINI, J. A.; COLLI, B. O.; TIRAPELLI, D. P. C.; TIRAPELLI, L. F. \& CARVALHO, C. A. M. MicroRNA-27b expression in rats submitted to physical exercise and experimental cerebral ischemia. Int. J. Morphol., 39(3):754-758, 2021.

showed signs of fatigue or poor adaptation to the treadmill had the exercise protocol interrupted. Electric shocks were not used and they were stimulated to run by small touches with the hands when necessary. In a persistent situation, the animal was removed from the treadmill to rest and recover. Training was only resumed when the animal was fully recovered.

MicroRNA identification. Diana Tools, TargetScan and miRWalk software and databases were used to identify and choose the target microRNA. A set of microRNAs were identified as differentially expressed and related to their potential target transcripts. Among the microRNAs identified, microRNA-27b was chosen.

Gene expression analysis. The real-time PCR method was used for the differential expression of the microRNA. From the cDNA obtained from the samples, real-time quantitative Polymerase Chain Reaction (PCR) amplification (RQ-PCR) was performed using the TaqMan Master Mix reagent (Applied Biosystems). The commercially available TaqMan Assayon-demand system, composed of oligonucleotides and probes (Applied Biosystems), was used for the quantitative analysis of microRNA expression. The data were then exported to Excel spreadsheets to calculate the DCT values. The GraphPad Prism 8.0 software (GraphPad Prism, Inc, San Diego, CA, USA) was used to generate the graphs and calculate the statistical significance. All reactions were performed in duplicate and analyzed on the 7500 Sequence Detection System (Applied Biosystems). The data were constantly collected during the PCR and analyzed in ABI7500 SDS "software package”.

Statistical analysis. The Kruskal-Wallis test, followed by the Bonferroni post-test, was performed using the GraphPad Prism software (GraphPad Software, San Diego, CA, USA). The level of significance was set at $p<0.05$ for two-tailed tests.

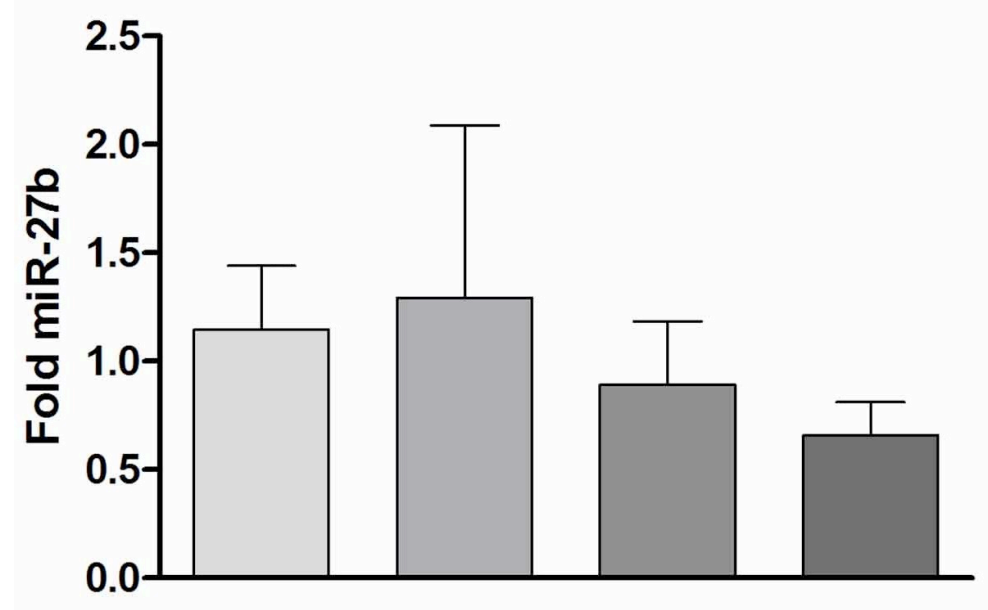

\section{RESULTS}

Figure 1 represents the average of the values ( \pm standard error) of microRNA-27b expression between the groups studied. In our study, we did not observe significant differences in the levels of expression of microRNA-27b between the Control, Physical Exercise, Cerebral Ischemia and Physical Exercise + Cerebral Ischemia Groups ( $p>0.05$, Kruskall Wallis test).

\section{DISCUSSION}

A study by Chang et al. (2019) demonstrated that early physical exercise can improve motor and neuronal recovery after stroke in rats. They showed an improvement in motor strength after early physical exercise. For patients, many guidelines involved in clinical practice recommend the early start of physical exercise for better recovery from a post-stroke physical disability (Bernhardt et al., 2008; Billinger et al., 2014).

Recently, da Silva et al. (2020), concluded that changes in microRNAs, both in muscle tissue and in body fluids, are associated with benefits induced by chronic physical exercise. Thus, microRNAs stand out as important targets of studies to elucidate the molecular pathways that are involved in the neuroprotection provided by previous physical exercise, during and after a stroke.

Rao et al. (2019) concluded that microRNA-217, in an in vitro model of ischemic injury, is involved in the regulation of oxygen-glucose deprivaed neurons, since its inhibition attenuated the neuronal injury induced by ischemia through positive regulation of SIRT1, AMPK-a and NF-kB.
Fig. 1. Representation of mean values $( \pm$ standard error) of the microRNA-27b expression in brain tissue between the groups studied. 
DE RUSSI, B. M.; PORSANI, L. B.; CIRINO, M. L. A.; SILVA, J. P.; TURRA, L. P.; NOVAIS, P. C.; LIZARTE NETO, F. S.; FAZAN, V. P. S.; THOMAZINI, J. A.; COLLI, B. O.; TIRAPELLI, D. P. C.; TIRAPELLI, L. F. \& CARVALHO, C. A. M. MicroRNA-27b expression in rats submitted to physical exercise and experimental cerebral ischemia. Int. J. Morphol., 39(3):754-758, 2021.

Also, microRNA-124 has effects on physiological and pathological processes involved in cerebral ischemia caused by stroke, since it regulates neuroinflammation, neuronal excitability and neurodifferentiation. It must therefore be considered not only as a diagnostic biomarker and indicator of the degree of brain damage in an ischemic brain event, but also as a therapeutic target for the treatment of stroke (Liu et al.).

This study aimed to evaluate the expression of microRNA-27b as a possible regulator of neurotransmitter receptors in rats submitted to physical exercise and experimental cerebral ischemia.

Cirino et al. evaluated the expression of microRNA15b, microRNA-29b, microRNA-219 and microRNA-222 in rats submitted to focal cerebral ischemia associated with physical exercise and found no significant differences between groups. Our results corroborate this study since we also did not observe significant differences in the expression levels of microRNA-27b between groups. Thus, we can suggest that the conditions of the experimental design, for example, the duration of the ischemia period and the reperfusion time, can be directly associated with the expression pattern of the studied microRNA.

Recent research has shown that microRNA-27b promotes, by downregulation, recovery after stroke by stimulating AMPK, protein kinase activated by adenosine monophosphate (Yuan et al., 2019). A study by Wang et al. (2019), investigating the association between microRNA$27 \mathrm{~b}$ and AMPK, demonstrated that, in a mouse middle cerebral artery occlusion model, the administration of microRNA-27b inhibitor significantly improved the recovery of its function behavioral and spatial memory.

Moreover, it was demonstrated, from a study by Shin et al. (2014), that the suppression of microRNA-27b is involved in the neuroprotection and migration ofneuronal progenitor cells in an induced sublethal ischemia, or ischemic preconditioning (IPC). Ischemic brain tissue, which was induced in C6 astrocytoma cells by IPC, increased the expression of stromal cell-derived factor 1 (SDF-1). It is reported that SDF-1 plays a role in neuroprotection after stroke by mediating the migration of neuronal progenitor cells. Overexpression of microRNA-27b suppressed the expression of SDF-1, while its negative regulation increased the expression of SDF-1. In conclusion, the suppression of microRNA-27b plays an important role in the neuroprotection of an ischemic brain event.

Thus, further studies are needed to elucidate the interaction between the expression of microRNA-27b and the pathophysiology of cerebral ischemia associated with physical exercise. Besides that, other microRNAs need to be evaluated, with different duration of cerebral ischemia as well as different periods of reperfusion.

DE RUSSI, B. M.; PORSANI, L. B.; CIRINO, M. L. A.; SILVA, J. P.; TURRA, L. P.; NOVAIS, P. C.; LIZARTE NETO, F. S.; FAZAN, V. P. S.; THOMAZINI, J. A.; COLLI, B. O.; TIRAPELLI, D. P. C.; TIRAPELLI, L. F. \& CARVALHO, C. A. MExpresión de MicroRNA-27b en ratas sometidas a ejercicio físico e isquemia cerebral experimental. Int. J. Morphol., 39(3):754$758,2021$.

RESUMEN: La isquemia cerebral no solo tiene una alta tasa de mortalidad y es la segunda causa principal de muerte en todo el mundo, sino también es la causa de enfermedades invalidantes en personas en edad laboral, lo que genera un gasto público enorme para el tratamiento y la rehabilitación de las personas afectadas. El papel de los microARN en la fisiopatología de la isquemia cerebral se ha destacado en las investigaciones actuales. Además, estudios recientes también han destacado el ejercicio físico como un posible factor protector tanto en la prevención como en los efectos de la isquemia cerebral, situándolo como un importante recurso de estudio. Por lo tanto, investigamos el papel del ejercicio físico en la isquemia cerebral experimental asociada con la expresión del microARN-27b. Se utilizaron 16 animales, divididos en cuatro grupos experimentales: Control, Ejercicio Físico, Isquemia Cerebral e Isquemia Cerebral asociada al Ejercicio Físico. Se utilizó la metodología de PCR en tiempo real para analizar la expresión de microARN-27b. Aunque no se observaron diferencias estadísticamente significativas en la expresión de microARN-27b entre los grupos estudiados, la mayor expresión de microARN-27b en el grupo de Ejercicio Físico indica su papel neuroprotector en la fisiopatología de la isquemia cerebral.

PALABRAS CLAVE: isquemia cerebral; Ejercicio físico; MicroARN; MicroARN-27b.

\section{REFERENCES}

Aguiar Jr., A. S. \& Pinho. R. A. Efeitos do exercício físico sobre o estado redox cerebral. Rev. Bras. Med. Esporte, 13(5):355-60, 2007.

Bao, T. H.; Miao, W.; Han, J. H.; Yin, M.; Yan, Y.; Wang, W. W. \& Zhu, Y.H.; Spontaneous running wheel improves cognitive functions of mouse associated with miRNA expressional alteration in hippocampus following traumatic brain injury. J. Mol. Neurosci., 54(4:622-9, 2014.

Bernhardt, J.; Dewey, H.; Thrift, A.; Collier, J. \& Connan, G. A very early rehabilitation trial for stroke (AVERT): phase II safety and feasibility. Stroke, 39(2):390-6, 2008.

Billinger, S. A.; Arena, R.; Bernhardt, J.; Eng, J. J.; Franklin, B. A.; Johnson, C. M.; Mackay-Lyons, M.; Macko, R. F.; Mead, G. E.; Roth, E. J.; et al. Physical activity and exercise recommendations for stroke survivors: a statement for healthcare professionals from the American Heart Association/American Stroke Association. Stroke, 45(8):2532-53, 2014.

Carlotti Junior, C. G.; Colli, B. O. \& Kazuo, J. Y.; Avaliação da isquemia cerebral pela respiração mitocondrial, Arq. Neuropsiquiatr., 59(2B):365$71,2001$. 
DE RUSSI, B. M.; PORSANI, L. B.; CIRINO, M. L. A.; SILVA, J. P.; TURRA, L. P.; NOVAIS, P. C.; LIZARTE NETO, F. S.; FAZAN, V. P. S.; THOMAZINI, J. A.; COLLI, B. O.; TIRAPELLI, D. P. C.; TIRAPELLI, L. F. \& CARVALHO, C. A. M. MicroRNA-27b expression in rats submitted to physical exercise and experimental cerebral ischemia. Int. J. Morphol., 39(3):754-758, 2021.

Chang, M. C.; Park, C. R.; Rhie, S. H.; Shim, W. H. \& Kim, D. Y. Early treadmill exercise increases macrophage migration inhibitory factor expression after cerebral ischemia/reperfusion. Neural Regen. Res., 14(7):1230-6, 2019.

Cirino, M. L. A.; Porsani, L. B.; Lizarte Neto, F. S.; Tazima, M. F. G. S.; Zimak, R. F.; Carlotti Jr., C. G.; Colli, B. O.; Tirapelli, L. F. \& Tirapelli, D. P. C. ResearchArticle Expression of miR-15b, miR-29b, miR-219 and miR-222 microRNAs in rats with focal cerebral ischemia submitted to physical exercise. Gen. Mol. Res., 18(4):gmr18213, 2019.

da Silva, F. C.; Iop, R. da R.; Andrade, A.; Costa, V. P.; Gutierres Filho, P. J. B. \& da Silva, R. Effects of physical exercise on the expression of MicroRNAs: a systematic review. J. Strength Cond. Res., 34(1):270$80,2020$.

Damázio, L. C. M.; Melo, R. T. R.; Lima, M. C.; Pereira, V. G.; Ribeiro, R. I. M. A.; Alves, N. R.; Monteiro, B. S.; Natali, A. J; Del Carlo, R. J. \& Costa Maldonado, I. R. S. C. Physical exercise promotes neuroprotection structural and functional in rats with cerebral ischemia. Rev. Neurocienc., 23(4):581-8, 2015.

Dornbos 3rd, D.; Zwagerman, N.; Guo, M.; Ding, J. Y.; Peng, C.; Esmail, F.; Sikharam, C.; Gengs, X.; Guthikonda, M. \& Ding, Y. Preischemic exercise reduces brain damage by ameliorating metabolic disorder in ischemia/reperfusion injury. J. Neurosci. Res., 91(6):818-27, 2013.

Downing, J. \& Balady, G. J. The role of exercise training in heart failure. J. Am. Coll. Cardiol., 58(6):561-9, 2011.

Feigin, V. L.; Forouzanfar, M. H.; Krishnamurthi, R.; Mensah, G. A.; Connor, M.; Bennett, D. A.; Moran, A. E.; Sacco, R. L.; Anderson, L.; Truelsen, T.; et al. Global and regional burden of stroke during 19902010: findings from the Global Burden of Disease Study 2010. Lancet, 383(9913):245-54, 2014.

Fernandes, J.; Arida, R. M. \& Gomez-Pinilla, F. Physical exercise as an epigenetic modulator of brain plasticity and cognition. Neurosci. Biobehav. Rev., 80:443-56, 2017.

Garbuzova-Davis, S.; Rodrigues, M. C. O.; Hernandez-Ontiveros, D. G.; Tajiri, N.; Frisina-Deyo, A.; Boffeli, S. M.; Abraham, J. V.; Pabon, M.; Wagner, A.; Ishikawa, H.; et al. Blood-brain barrier alterations provide evidence of subacute diaschisis in an ischemic stroke rat model. PLoS One, 8(5):e63553, 2013.

Liu, X.; Feng, Z.; Du, L.; Huang, Y.; Ge, J.; Deng, Y. \& Mei, Z. The potential role of MicroRNA-124 in cerebral ischemia injury. Int. J. Mol. Sci., 21(1):120, 2019.

Rao, G.; Zhang, W. \& Song, S. MicroRNA-217 inhibition relieves cerebral ischemia/reperfusion injury by targeting SIRT1. Mol. Med. Rep., 20(2):1221-9, 2019.

Shamsaei, N.; Khaksari, M.; Erfani, S.; Rajabi, H. \& Aboutaleb, N. Exercise preconditioning exhibits neuroprotective effects on hippocampal CA1 neuronal damage after cerebral ischemia. Neural Regen. Res., 10(8):1245-50, 2015.

Shin, J. H.; Park, Y. M.; Kim, D. H.; Moon, G. J.; Bang, O. Y.; Ohn, T. \& Kim, H. H. Ischemic brain extract increases SDF-1 expression in astrocytes through the CXCR2/miR-223/miR-27b pathway. Biochim. Biophys. Acta, 1839(9):826-36, 2014.

Sveinsson, O. A.; Kjartansson, O. \& Valdimarsson, E. M. Cerebral ischemia/ infarction - epidemiology, causes and symptoms. Laeknabladid, 100(5):271-9, 2014.

Wanchao, S.; Chen, M.; Zhiguo, S.; Futang, X. \& Mengmeng, S. Protective effect and mechanism of Lactobacillus on cerebral ischemia reperfusion injury in rats. Braz. J. Med. Biol. Res., 51(7):e7172, 2018.

Wang, Z.; Yuan, Y.; Zhang, Z. \& Ding, K. Inhibition of miRNA-27b enhances neurogenesis via AMPK activation in a mouse ischemic stroke model. FEBS Open Bio., 9(5):859-69, 2019.

Yuan, Y.; Zhang, Z.; Wang, Z. \& Liu, J. MiRNA-27b regulates angiogenesis by targeting AMPK in mouse ischemic stroke model. Neuroscience, 398:12-22, 2019.
Corresponding author:

Brenno Marco De Russi

Universidade de São Paulo

Faculdade de Medicina de Ribeirão Preto

Departamento de Cirurgia e Anatomia Ribeirão Preto - SP

BRASIL

Email: lab.biomol.cirurgia@fmrp.usp.br

Received: 05-01-2021

Accepted: 17-03-2021 